3. Поташник М.М. Управление профессиональным ростом учителя в современной школе / М.М. Поташник. - М. : Центр педагогического образования, 2009. - 448 с.

4. Педагогический энциклопедический словарь / гл. ред. Б.М. Бим-Бад - М. : Большая Российская энциклопедия, 2002. - 528 с.

5. Сборник нормативных и методических материалов для организации экспериментальной работы в общеобразовательных школах Автономной Республики Крым: метод.пособие / Сост. Глузман А. В., Игнатенко Н. Я., Пономарева Е.Ю. - Ялта : РМО РВУЗ «КГУ», 2009. - 108 с.

6. Штофф В.А. Моделирование и философия / В.А. Штофф. - М., 1966. - 296 с. Стаття надійшла до редакції 12.04.2012 р. викладач, КіровоградськийДПУ імені Володимира Винниченка

\title{
УПРОВАДЖЕННЯ ПРИНЦИПУ КУЛЬТУРОВІДПОВІДНОСТІ У ХУДОЖНЬО-ТРУДОВІЙ ДІЯЛЬНОСТІ УЧНІВ НА УРОКАХ ТЕХНОЛОГІЙ
}

\footnotetext{
Чистякова Л. О. Упровадження принципу культуровідповідності у художньо-трудовій діяльності учнів на уроках технологій.

У статті розкрито суть принципу культуровідповідності у художньо-трудовій діяльності. Розглянуто можливість дотримання иьього принщипу в сучасній школі на уроках технологій.

Ключові слова: культура, культуровідповідність, творчість, художньо-трудова діяльність.

Чистякова Л. А. Внедрение приниипа культуросоответствия в художественно-трудовой деятельности учеников на уроках технологий.

В статье раскрыта суть принципа культуросообразности в художественно-трудовой деятельности. Рассмотрена возможность сюблюдения этого принципа в современной школе на уроках технологий.

Ключевые слова: культура, культуросообразность, творчество, художественно-трудовая деятельность.

Chistyakova L. The introduction of the principle of cultural appropriateness in the artistic work of students in class technology.

The article reveals the essence of the culturally grounded in art and labour activity. It considers the facilities of adhering to this principle at contemporary school on the lessons technology.

Key words: culture, cultural cross-reference, creativity, art and labour activity.
}

Необхідною умовою гармонійного і цілісного розвитку особистості учня в загальній середній освіті є якісна технологічна освіта, складником якої $є$ предметно-перетворювальна діяльність. Саме уроки технологій мають значні можливості для залучення учнів до художньо-трудової діяльності, яка завершується створенням предметів, що відображають світ краси, творчості, культури та духовної спадщини народу, яка виховує поважне ставлення до праці, формує моральні якості особистості, естетичні смаки.

Залучення підростаючого покоління до різноманітних видів художньотрудової діяльності, започаткованої у народних ремеслах та промислах, індивідуальне виготовлення предметів, що поєднують утилітарно-вжиткові 
та художньо-декоративні якості, можна вважати передумовою успішної освіти. Вивчення народного мистецтва, яке вирізняється високими естетичними перевагами, активно впливає й на формування особистості учня, сприяє становленню його майстерності, формує самовираження у художньо-трудовій творчості.

Предметно-перетворювальна діяльність та ii важливий складник художньо-трудова має надзвичайні можливості для цілісного фізичного, інтелектуального, соціального та духовного розвитку особистості учня, здійснення особистісно орієнтованого підходу у формування творчих можливостей дітей. Адже українське народне декоративне мистецтво унікальне явище національної культури. Воно завжди правдиво висвітлювало світові життя нації, іiі духовне багатство, рівень культури, творчі сили і здібності, енергію, виступало як феномен незнищеності.

У Концепції технологічної освіти учнів загальноосвітніх навчальних закладів (автори О. Коберник та В. Сидоренко) [6] наголошується, що важливим напрямом технологічної освіти $є$ залучення учнів до збереження та розвитку національних трудових традицій, відродження характерних для даного регіону народних ремесел і промислів.

Відповідно до Концепції в основу технологічної освіти учнів покладено як загальнодидактичні (наочності, науковості, систематичності, зв'язку 3 життям, доступності, свідомості й активності, міцності знань, індивідуалізації та диференціації, емоційності), так і специфічні принципи навчання (культуровідповідності, природовідповідності, творчості, варіативності, інтегративності, диференціації, системності, ергономічності, педагогічного проектування).

3-поміж специфічних принципів навчання технологій чільне місце посідає принцип культуровідповідності. Саме цей принцип передбачає органічний та нерозривний зв’язок з історією народу, його культурними i побутовими традиціями, народним мистецтвом, ремеслами і промислами, забезпечення духовної єдності та спадкоємності поколінь. Загальновідомо, що у культурі народу акумульовано творчу енергію багатьох поколінь, яке $\epsilon$ могутнім чинником творчого розвитку кожної людини.

3 давніх часів людство усвідомлювало важливість залучення молодого покоління до здобутків етнокультури. Так, органічно здійснювалася підготовка дітей до життя. Культуровідповідність була однією 3 найважливіших складників процесу виховання, передбачала сукупність умінь і навичок у опануванні традиційних культурних цінностей i створенні власного продукту відповідно до вікових періодів. Тому багато педагогів займалися проблемою теоретичного обгрунтування ідеї культуровідповідності.

Значний внесок у розвиток ідеї культуровідповідності зробив А. Дістервег. Його праця «Про природовідповідність і культуровідповідність у навчанні» [2] досконало обгрунтовує ідею культуровідповідності виховання. Педагог був глибоко переконаний у тому, що: «Кожна людина знаходить при своєму народженні на світ своє оточення, свій народ, серед якого їй призначено жити і принаймні виховуватися уже на певному ступені 
культури, яку повинні розглядати як спадок, залишений предками, як результат їхньої історії та всіх чинників, що на них впливали» [2, с. 229]. Автор наголошує, що: «...потрібно зважати на звичаї, традиції, які наявні у суспільстві, на все, що в ньому визначається й прийнято» [2, с. 230]. Саме А. Дістервег визначив культуровідповідність як принцип і вважав його як «непохитний, непорушний» [2, с. 231].

Нині поняття культури використовується в двох аспектах, а саме: як всеохоплююча сукупність надбань загальнолюдської свідомості або ж як сфера духовних інтересів суспільства. За визначенням Д. Антоновича, «у широкому розумінні цього слова культурою вважаються все, що має людина чи громада людей не від природи, а від власного розуму і власної творчості, як у царині матеріальній, так і в духовній, у галузі громадського життя, звичаїв і побуту» [9, с. 17].

Дещо інший зміст вкладає в поняття культури М. Каган, який услід за Е. Тейлором стверджує: «Культура або цивілізація в широкому етнографічному розумінні складається в одне ціле із знань, вірувань, мистецтва, моралі, законів, звичаїв та деяких інших здібностей і звичок, засвоєних людиною як членом суспільства» [4, с. 186]. У цьому визначенні, на наш погляд, дещо змішується культурний потенціал цивілізації із скромними можливостями окремої людини.

На наш погляд, найбільш удале визначення культури пропонує I. Крип’якевич, який зазначив, що «...нема дотепер - i, мабуть, ніколи не буде - загально прийнятої дефініції, що таке культура. Одні розуміють під цією назвою всі здобутки тисячолітньої праці людства як на матеріальному полі, так i на духовному та в обсяг культури раді 6 взяти всі прояви людського життя. Другі думають, що до культури треба віднести тільки розвиток продукції, винаходів, поступ у виробництві і взагалі обмежуються так званою матеріальною культурою. Інші, навпаки, бачать культуру щойно на верхах духовного розвитку людини - в мистецтві, науці, філософії. Одні бажають звести історію культури до досліду постійних, типових форм життя, інші ціну культури бачать в їі різнорідності...» [3, с. 3].

Можемо зробити висновок, що культура поєднує матеріальні й духовні надбання певної нації. Недаремно А. Канцедикас [5] зазначав, що відокремлення інтелектуальної, художньої, релігійної й іншої діяльності від матеріального виробництва є абсолютно необгрунтованим стосовно народної культури, і прямим підтвердженням цього є утилітарно-естетичний характер народного мистецтва.

Надзвичайно важливим є висвітлення місця в національній культурі предметного мистецтва, зокрема декоративно-ужиткового. Постійне перебування особистості під впливом матеріальної i духовної культури рідного народу необхідне для найповнішого розкриття і розвитку природних здібностей, оскільки саме за таких умов етнопсихологічні особливості дітей певного народу використовуються найдоцільніше. 
Слушність таких думок доводиться прогностичними висновками А. Канцедикаса, який услід за польським соціологом В. Павлючком повторює: «Найважливішим завданням нашого часу має бути новий синтез різноманітних аспектів життя індивіда й суспільства, нова єдність світу людини... Культура постіндустріальної епохи буде, 3 цього погляду, ідентичною народній культурі в іiі запереченні негативних рис сучасності: дегуманізації праці, розриву між цивілізацією і культурою, пасивною участю в культурному процесі тощо. Ідентичність цієї культури народній культурі буде виявлятися насамперед у тому, що це знову буде культура, де всі творіння людських рук і людського розуму будуть виражати людину у всій іiі повноті, у їі всебічних зв'язках із суспільством і світом» [5, с. 65].

Нині багато науковців відстоюють думку збереження та примноження етнокультури, залучення до неї дітей та молоді. Також сучасними педагогами формулюється принципи мультикультурної освіти, серед яких визначаються «етнокультурна спрямованість освіти; етнопедагогізація освітнього процесу, діалог культур; творча доцільність використання, збереження і створення нових культурних цінностей» [7, с. 41].

Реалізація принципу культуровідповідності значною мірою здійснюється у художньо-трудовій діяльності учнів на уроках технологій у процесі опанування модулів з циклу декоративно-прикладного мистецтва.

Художньо-трудова діяльність - це один із видів предметноперетворювальної діяльності, яка спрямована на засвоєння знань і формування вмінь і навичок з декоративно-прикладного мистецтва як елементів культурної спадщини українського народу. Водночас вона $\epsilon$ основою художньоестетичного виховання, спрямованого на розвиток національної самосвідомості учня. Але така діяльність справляє на особистість розвивальний вплив лише за умови, якщо вона викликає в неї позитивну реакцію (ставлення) і збуджує їі власну активність у роботі над собою.

Декоративно-прикладне мистецтво є складовою частиною предметноперетворювальної діяльності учнів, де людина розкриває і розвиває свої сутнісні сили, засвоює i закріплює найважливіші соціально-моральні цінності, синтезуючи мистецтво і фізичну працю.

Найбільш повне визначення i характеристику декоративноприкладного мистецтва спостерігаємо в дослідженнях К. Духанкіна, Ф. Сгорова, Б. Лукінова, К. Сєдова та Я. Чернецького, які зазначають: «Предмети декоративно-прикладного мистецтва - це виготовлені й художньо оздоблені кустарним чи промисловим способом побутові речі, що мають не тільки практичне, а й естетичне значення. Поверхня цих речей оформлена таким способам, що декорування не вступає у суперечність 3 утилітарною формою, а пербуває у тісному зв'язку з нею, утворюючи одне ціле. До таких речей належать художньо оздоблений посуд і одяг, меблі, декоративні тканини, килими, вишивка, мереживо і тощо»[1,с. 231].

Декоративно-прикладне мистецтво охоплює широке коло предметів із різних галузей людської діяльності. Для їх виготовлення використовують 
різноманітні матеріали: метал, дерево, глина, кістка, камінь, скло, штучні матеріали, вовна, льон тощо. Результатом декоративно-ужиткової творчості є предмети і речі, призначені для практичного використання. Їх декоративність визначається формою об'єкта діяльності, матеріалом, з якого вона виготовлена, a також художнім обробленням i оздобленням: розписом, різьбленням, нанесенням рельєфу, лаковим покриттям тощо. Це означає, що початковим етапом роботи є матеріальне творення предмета шляхом ліплення (глина), вирізування, виточування, випилювання, збивання, склеювання, зварювання, ткання, розкроювання, зшивання (тканини, волокнисті матеріали) тощо.

Варто підкреслити, що десятки тисяч років тому людська культура зароджувалася саме на основі трудової діяльності й була синкретичною, тобто нероздільною. Мистецтво в ті часи не поділялось на види, але навіть не відокремилося від виробничої діяльності людини, було одним із іi складових, тісно перепліталося з віруваннями і обрядами [3].

Обов'язковими вимогами декоративно-прикладного мистецтва $є$ доцільність форми предмета та відсутність суперечності між його декоративною i ужитковою функціями. Витвори цього виду мистецтва мають риси національних традицій, які втілюються у формі предмета, матеріалів й техніці його оброблення, художніх сюжетів і орнаментальних мотивах декорування.

Нині навчальні програми 3 трудового навчання надають вчителеві широкий вибір тем у напрямку декоративно-прикладної творчості. Зокрема, у навчальній програмі «Трудове навчання. 5-9 кл. Нова редакція» та у проекті Навчальна програма «Трудове навчання. 5-9кл.», що розроблена відповідно до вимог Державного стандарту базової та повної загальної середньої освіти, інваріантна та варіативна складаються із модулів, що у повному обсязі охоплюють усі види декоративно-прикладного мистецтва. Це і технологія виготовлення виробів з дерева та металу, аплікація, вишивання, в’язання гачком та спицями, плетіння з бісеру, писанкарство, виготовлення народної ляльки тощо. Причому учитель може сам обирати варіативний модульу залежності від матеріально-технічної бази, фахової підготовленості, регіональних традицій. Все це сприяє оволодінню учнями системою знань та практичних умінь з декоративно-прикладного мистецтва, залучає дітей до створення предметів світу краси, вводить школярів у неповторний світ національної культури.

Створюючи зразки духовної та матеріальної культури, особистість розвиває і реалізує свій творчий потенціал. Найбільш прийнятним, як переконує досвід, коли джерелом розкриття творчих потенцій стає рідна культура. Вивчення народного мистецтва, яке характеризується високими естетичними перевагами, активно впливає на формування особистості.

\section{Література}

1. Виды изобразительного искусства / К.П. Духанкин, Ф.И. Егоров, Б. П. Лукинов и др.]. - Л. : Госучпедгиз, 1959. - 273 с.

2. Дистервег Ф.- В.-А. О природосообразности и культуросообразности в обучении /Ф.- В.-А. Дистервег // Избр.пед. соч. - М. : Учпедгиз, 1956. - 374 с. 
3. Історія української культури/ під заг. ред. І. Крипякевича. - Львів : Вид-во Івана Тиктова, 1937. - $1036 \mathrm{c.}$

4. Каган М. С. Человеческая деятельность (Опыт системного анализа) / М.С. Каган. М. : Политиздат, 1974. - 328 с.

5. Канцедикас А. Искусство и ремесло. К вопросу о природе народного искусства / А. Канцедикас. - М. : Изобр. искусство, 1977. - 120 с.

6. Концепція технологічної освіти учнів загальноосвітніх навчальних закладів України [Електронний ресурс]. - Режим доступу : // http://www.rer.ptosvita.org. - Загол. з екрану

7. Палаткина Г.В. Мультикультурное образование: современный поход к воспитанию на народных традициях / Г.В. Палаткина // Педагогика. - 2002. - №5.

Стаття надійшла до редакції 17.04.2012 р.

УДК 373.5.016:53

Н. В.Форкун, аспірант,

Кам'янещь-Подільський національний університет імені Івана Огієнка

\section{КОМПЕТЕНТНІСНИЙ ПІДХІД ДО ВИКЛАДАННЯ ФІЗИКИ У СТАРШІЙ ШКОЛІ}

Форкун Н. В. Компетентнісний підхід до викладання фізики у старшій школі.

У статті розглянуто шляхи реалізації компетентнісного підходу до викладання фізики у старшій школі.

Ключові слова: компетентнісний підхід, старша школа, фізика, інтелект-карта.

Форкун Н. В. Компетентносный подход к преподаванию физики в старшей школе.

В статье рассмотрены пути реализации компетентностного подхода к преподаванию физики в старшей школе.

Ключевые слова: компетентностный подход, старшая школа, физика, интеллект-карта.

Forkun N. Competence approach to teaching physics in high school.

In the article reviews ways to implement the competence approach in the process of study of physics of senior school pupils.

Key words: competence approach, physics, senior school, mind map.

Постановка проблеми. Суспільство вимагає виховання самостійних, ініціативних і відповідальних громадян, здатних ефективно взаємодіяти у розв'язанні соціальних, виробничих та економічних завдань. У світлі приєднання України до Болонського процесу змін потребує не лише процес навчання у вищій школі, але й навчання у старшій школі, яке є невід'ємною й важливою сходинкою до вищої освіти. Компетентнісний підхід у шкільній освіті є вимогою часу.

Аналіз актуальних досліджень. Проблемами компетентнісного підходу до навчання цікавляться багато науковців: як вітчизняних, так і зарубіжних. Дослідженням теорії, методики, умов впровадження компетентнісного підходу до навчального процесу займаються П. Атаманчук, С. Величко, О. Іваницький, А. Заболотний, О. Пометун, О. Савченко, О. Овчарук, А. Хуторський та інші. Однак, незважаючи на суттєві наукові, теоретичні розробки, проблема практичної реалізації компетентнісного підходу до навчання фізики у старшій школі залишається відкритою. 